\title{
KOMODITAS UNGGULAN SUBSEKTOR TANAMAN PANGAN BERBASIS POTENSI WILAYAH KERUANGAN DI PROVINSI BALI
}

\author{
Superior Commodities of Food Crops Subsector Based \\ on Potential Spatial Areas in Bali Province
}

\author{
Evendi Akhmadi, Made Antara \\ Program Studi Magister Agribisnis, Fakultas Pertanian, Universitas Udayana, Bali, Indonesia \\ Email:akhmadevendi@gmail.com
}

\begin{abstract}
Food crop commodities in Bali are quite potential, so making these commodities quite crucial in various discussions. When viewed from the results of the 2013 Agriculture Census in Bali there were 408,233 agricultural business households and 53 percent of them were food crop business households. Bali's GRDP according to business fields, food crops subsector contributed 14.57 percent of the 2016 GDP contribution to the agricultural sector. The development of tourism and population growth are thought to be the cause of the conversion of agricultural land to non-agriculture. Therefore, a scientific study is needed to map the potential of the food crop subsector in Bali. The objectives of this study are: (1) to identify what are the main competitive seed crops, (2) to analyze the growth of food crops according to districts / cities, (3) to analyze the potential of the main commodity areas of Bali's food crops. This research was conducted in Bali Province. The selection of research locations using the purposive sampling method is based on the consideration that food crops are the most sought-after commodities by Balinese farmers. The data used in this study is the data on commodity production of the Bali Province food crops sub-sector according to districts / cities in the 5-year time series (2011-2015). The analytical tool used is Location Quotient (LQ), Shift Share, Superimpose and analysis of potential spatial areas. The results of the study show that all regencies I municipalities have comparative superior food crops except the city of Denpasar. Increased regional growth of food crops occurred in three districts / cities, namely Jembrana, Gianyar and Denpasar City. All districts / cities have food crops that experience proportional rapid growth, high competitiveness commodities and commodities that are progressing in net growth. All regencies have superior crops of food commodities, both those which are superior (comparative or competitive superior) and highly superior (comparative and competitive) commodities. Meanwhile, Denpasar City only has superior food crops (competitively superior).
\end{abstract}

Keywords: food crops, superior commodities, comparative advantage, competitive advantage

\begin{abstract}
ABSTRAK
Komoditas tanaman pangan di Bali yang cukup potensial, sehingga menjadikan komoditas tersebut cukup krusial dalam berbagai bahasan. Jika dilihat hasil Sensus Pertanian 2013 di Bali terdapat 408.233 rumah tangga usaha pertanian dan 53 persen diantaranya rumah tangga usaha tanaman pangan. PDRB Bali menurut lapangan usaha, subsektor tanaman pangan memberikan kontribusi sebesar 14,57 persen dari nilai kontribusi PDRB untuk sektor pertanian tahun 2016. Berkembangnya pariwisata dan pertumbuhan jumlah penduduk ditengarai menjadi penyebab konversi lahan pertanian ke non pertanian. Oleh karena itu, diperlukan sebuah kajian ilmiah guna memetakan potensi subsektor tanaman pangan di Bali. Tujuan penelitian ini adalah: (1) mengidentifikasi apa sajakah komoditas tanaman pangan yang menjadi unggulan komparatif, (2) menganalisis pertumbuhan komoditas tanaman pangan menurut kabupaten/kota, (3) menganalisis potensi wilayah keruangan komoditas unggulan tanaman pangan wilayah Bali. Penelitian ini dilakukan di Provinsi Bali. Pemilihan lokasi penelitian dengan metode purposive sampling didasarkan atas pertimbangan bahwa komoditas tanaman pangan merupakan komoditas yang paling banyak diusahakan oleh petani Bali. Data yang digunakan dalam penelitian ini merupakan data produksi komoditas subsektor tanaman pangan Provinsi Bali menurut kabupaten/kota dalam runtun waktu (time series) 5 tahun (2011-2015). Alat analisis yang digunakan yaitu Location Quotient (LQ), Shift Share, Superimpose dan analisis potensi wilayah keruangan. Hasil penelitian menunjukkan bahwa semua wilayah kabupaten/kota memiliki komoditas tanaman pangan unggulan komparatif kecuali Kota Denpasar. Peningkatan pertumbuhan regional komoditas tanaman pangan terjadi di tiga kabupaten/kota yaitu Jembrana, Gianyar dan Kota Denpasar. Semua kabupaten/kota memiliki komoditas tanaman pangan yang mengalami pertumbuhan yang cepat secara proporsional, komoditas dengan daya saing tinggi dan komoditas yang mengalami kemajuan dalam pertumbuhan bersih. Semua wilayah kabupaten memiliki komoditas unggulan tanaman pangan, baik yang termasuk komoditas unggul (unggul secara komparatif atau kompetitif) maupun komoditas sangat unggul (unggul secara komparatif dan kompetitif). Sedangkan Kota Denpasar hanya memiliki komoditas tanaman pangan unggul (unggul secara kompetitif).
\end{abstract}

Kata kunci: tanaman pangan, komoditas unggulan, keunggulan komparatif, keunggulan kompetitif 


\section{PENDAHULUAN}

Tanaman pangan merupakan komoditas strategis dan menarik dalam kaitannya dengan isu peningkatan produksi dan jaminan ketersediannya. Kebutuhan pangan akan terus mengalami peningkatan sejalan dengan pertambahan jumlah penduduk. Pemerintah melalui Badan Pusat Statistik dengan programnya yaitu Sensus Pertanian, melakukan pendataan potensi pertanian diseluruh Indonesia termasuk Provinsi Bali. Hasil dari sensus tersebut sebanyak 408.233 rumah tangga usaha pertanian dan 218.591 diantaranya rumah tangga usaha tanaman pangan. Sedangkan dari sisi penggunaan lahan di Bali tahun 2016 tercatat 62,71 persen atau 353.491 hektar penggunaan lahan adalah untuk lahan pertanian. Dari angka tersebut, 22,49 persen atau 79.526 hektar diantaranya merupakan lahan persawahan dan sisanya 77,51 persen merupakan lahan bukan sawah digunakan untuk kegiatan pertanian lainnya. Potensi pertanian dalam share PDRB Provinsi Bali menurut lapangan usaha tahun 2016 mencapai 14,74 persen. Kendati berada diperingkat dua dalam urutan share PDRB yang artinya sektor pertanian menjadi penopang kedua dari perekonomian Bali, sektor pertanian menyumbangkan kontribusi lapangan usaha yang paling dominan. Jika melihat dari sisi per subsektornya, dari tahun 2012-2016 trend share PDRB subsektor tanaman pangan menunjukkan penurunan tiap tahunnya. Hal ini menjadi tantangan bagi pemerintah untuk memenuhi ketersediaan kebutuhan pangan, mengingat subsektor tanaman pangan mempunyai peranan penting dalam penyediaan pangan bagi penduduk.

Keberadaan komoditas unggulan pada suatu daerah dapat memudahkan upaya pengembangan agribisnis. Penentuan komoditas unggulan dirasa sangat penting, karena dengan diketahuinya komoditas unggulan, maka fokus pengembangan terhadap komoditas tersebut menjadi prioritas. Namun demikian, hal tersebut tentunya tidak mengabaikan komoditas non unggulan lainnya. Selain itu, dengan fokus pada pengembangan komoditas unggulan dapat diupayakan peningkatan nilai tambah pada komoditas tersebut (Sitorus, dkk. 2014). Untuk dapat mengetahui peta potensi wilayah komoditas sebaran tanaman pangan menurut wilayah kabupaten/kota se-Bali, perlu dilakukan analisis Location Quotient (LQ). Masing-masing kabupaten mempunyai potensi komoditas unggulan, oleh karena itu perlu adanya analisa yang berbasis kewilayahan guna memetakan komoditas unggulan subsektor tanaman pangan di Bali menurut kabupaten/kota.

Menurut Mulyono (2016), pengembangan pertanian ke depan berbasis pada potensi dan komoditas unggulan wilayah setempat. Setiap wilayah memiliki komoditas unggulan masing-masing, bergantung pada sumberdaya yang dimiliki. Djaenudin et al. (2002) menyatakan bahwa pendekatan potensi wilayah komoditas pertanian dapat mengatasi penggunaan lahan yang kurang produktif menuju penggunaan lahan dengan komoditas unggulan yang lebih produktif. Syafruddin et al. (2004) mengungkapkan bahwa untuk membangun pertanian yang kuat, produktivitas tinggi, efisien, berdaya saing tinggi dan berkelanjutan diperlukan penataan sistem pertanian dan penetapan komoditas unggulan disetiap wilayah pengembangan.

Penelitian mengenai komoditas unggulan sudah banyak dilakukan, namun sebatas penentuan komoditas unggulan menggunakan analisis Location Quotient (LQ) atau Shift Share Analysis (SSA) saja, belum dikaitkan dengan potensi wilayah keruangan setiap kabupaten/kota dalam lingkup satu provinsi. Susrusa (2008) melakukan penelitian tentang identifikasi dan zonasi komoditas pertanian unggulan di Kabupaten Klungkung. Hasil penelitian ini menunjukan bahwa terdapat 16 komoditas pertanian unggulan yang masuk dalam komoditas tanaman pangan, perkebunan, peternakan dan perikanan. Pranoto (2008) melakukan penelitian tentang potensi wilayah komoditas pertanian dalam mendukung ketahanan pangan berbasis agribisnis di Kabupaten Banyumas. Hasil penelitian ini menunjukan bahwa potensi bahan pangan sumber karbohidrat berada pada tingkat yang aman. Kabupaten Banyumas masih memiliki potensi besar untuk menjadi daerah yang mandiri dalam penyediaan bahan pangan. Setiowati (2010) melakukan penelitian tentang komoditas unggulan sektor pertanian di Kabupaten Bangli. Hasil penelitian ini menunjukan bahwa sektor pertanian adalah sektor unggulan dalam perekonomian Kabupaten Bangli. Pada penelitian tersebut penentuan komoditas unggulan komparatif menggunakan alat analisis Location Quotient (LQ).

Menurut BPS Provinsi Bali (2017) luas wilayah Provinsi Bali secara keseluruhan mencapai 5.636,66 $\mathrm{km}^{2}$. Penggunaan lahan Provinsi Bali tahun 2016 tercatat sebesar 353.491 hektar atau 62,71 persen dari total luas lahan digunakan untuk lahan pertanian dan sisanya 210.175 hektar atau 37,29 persen digunakan untuk lahan bukan pertanian. Sementara itu, lahan pertanian terdiri dari lahan sawah 79.526 hektar atau 22,50 persen dan sisanya lahan bukan sawah 273.965 hektar atau 77,50 persen dari luas lahan pertanian. Tujuan penelitian ini adalah mengidentifikasi apa sajakah komoditas tanaman pangan yang menjadi unggulan komparatif dan menganalisis pertumbuhan komoditas tanaman pangan menurut kabupaten/kota serta menganalisis potensi wilayah keruangan komoditas unggulan tanaman pangan wilayah Bali.

\section{METODE PENELITIAN}

\section{Sumber Data}

Penelitian ini dilakukan di Provinsi Bali yang ditentukan secara sengaja (purposive sampling) yang didasarkan atas beberapa pertimbangan yaitu subsektor tanaman pangan merupakan subsektor yang paling banyak diusahakan oleh petani Bali. Analisis dalam penelitian ini menggunakan data kuantitatif, berupa data sekunder yang bersumber dari Badan Pusat Statistik (BPS) Provinsi Bali. Data yang digunakan dalam penelitian ini merupakan data produksi komoditas subsektor tanaman pangan Provinsi Bali menurut kabupaten/kota dalam runtun waktu (time series) 5 tahun (2011-2015). 


\section{Keunggulan Komparatif Komoditas Tanaman Pangan}

Keunggulan komoditas unggulan komparatif ditentukan melalui analisis Location Quotient (LQ) dengan kriteria LQ > 1. Analisis ini digunakan untuk mengidentifikasi komoditas subsektor tanaman pangan unggulan dan bukan unggulan secara komparatif pada suatu daerah. Teknik analisis ini membandingkan antara kemampuan suatu daerah dalam menghasilkan suatu komoditas dengan daerah lain yang merupakan penghasil komoditas yang sama. Konsep tersebut dapat diformulasikan sebagai berikut (Warpani, 1984 dalam Pranoto, 2008)

$L Q=\frac{S i / N i}{S / N}=\frac{S i / S}{N i / N}$

Keterangan:

LQ = Besarnya koefisien lokasi komoditas tanaman pangan.

$\mathrm{Si}=$ Jumlah (produksi) komoditas $\mathrm{i}$ pada tiap kabupaten/kota

$\mathrm{S} \quad=$ Jumlah (total produksi) tanaman pangan tingkat kabupaten/kota

$\mathrm{Ni}=$ Jumlah produksi komoditas $\mathrm{i}$ pada tingkat provinsi.

$\mathrm{N}=$ Jumlah total produksi komoditas tanaman pangan tingkat provinsi.

\section{Pertumbuhan Komoditas Tanaman Pangan}

Pertumbuhan komoditas tanaman pangan diukur melalui Shift Share Analysis (SSA). Menurut Budiharsono (2001) komponen analisis tersebut sebagai berikut:

a. Pertumbuhan Regional

Pertumbuhan regional digunakan untuk melihat perkembangan pertumbuhan komoditas tanaman pangan secara regional. Nilai positif pada pertumbuhan regional sebagai indikator bahwa komoditas tanaman pangan tersebut mengalami peningkatan share produksi secara regional. Sedangkan nilai negatif sebagai indikator share produksi pertumbuhan regional yang mengalami penurunan.

b. Pertumbuhan Proporsional

Pertumbuhan proposional digunakan untuk mengukur perubahan relatif, pertumbuhan atau penurunan produksi suatu komoditas tanaman pangan tertentu di wilayah kabupaten/kota dibandingkan dengan produksi seluruh komoditas tanaman pangan di kabupaten/kota. Nilai pertumbuhan proporsional positif menunjukan pertumbuhan komoditas tanaman pangan tertentu di tingkat kabupaten termasuk cepat.

c. Pertumbuhan Pangsa Wilayah

Pertumbuhan pangsa wilayah digunakan untuk mengukur seberapa besar daya saing atau keunggulan kompetitif suatu komoditas pangan tertentu di tingkat wilayah kecamatan dibandingkan dengan total komoditas yang sama di tingkat wilayah kabupaten/kota. Nilai pertumbuhan pangsa wilayah positif menunjukan komoditas pangan tertentu pada tingkat wilayah tersebut mempunyai keunggulan kompetitif atau daya saing yang lebih tinggi dibandingkan pada komoditas yang sama pada wilayah yang lebih luas (kabupaten/kota).

d. Pertumbuhan Bersih
Analisis pertumbuhan bersih digunakan untuk mengukur nilai koefisien nett dari pertumbuhan proporsional dan pertumbuhan pangsa wilayah. Pertumbuhan bersih diperoleh dari hasil penjumlahan antara pertumbuhan proporsional dan pertumbuhan pangsa wilayah. Nilai pertumbuhan bersih positif dapat diartikan pertumbuhan bersih komoditas tertentu pada suatu wilayah termasuk dalam kelompok progresif atau mengalami kemajuan. Sebaliknya jika nilai PBij negatif maka pertumbuhan bersih komoditas tertentu termasuk dalam kelompok lambat.

Adapun formulasi dari komponen tersebut

$P R=\frac{Y^{\prime} \ldots}{Y \ldots}-1$

$P P i j=\left(\frac{Y^{\prime} i}{Y i}-\frac{Y^{\prime} \ldots}{Y \ldots}\right)$

$P P W i j=\left(\frac{Y^{\prime} i j}{Y i j}-\frac{Y^{\prime} i}{Y i}\right)$

$P B i j=P P i j+P P W i j$

Keterangan:

$\mathrm{PR} \quad=$ Pertumbuhan Regional

PPij = Pertumbuhan Proporsional

PPWij = Pertumbuhan Pangsa Wilayah

PBij = Pertumbuhan Bersih

$\mathrm{Y}^{\prime} \ldots=$ Jumlah total produksi seluruh komoditas tanaman pangan tingkat kabupaten/kota pada tahaun $\mathrm{t}$ (terakhir).

$\mathrm{Y} \ldots=$ Jumlah total produksi seluruh komoditas tanaman pangan tingkat kabupaten/kota pada tahun $\mathrm{p}$ (permulaan)

$\mathrm{Y}^{\prime} \mathrm{i}=$ Jumlah produksi komoditas $\mathrm{i}$ pada tingkat kabupaten/kota pada tahun $\mathrm{t}$ (terakhir)

$\mathrm{Yi}=$ Jumlah produksi komoditas $\mathrm{i}$ pada tingkat kabupaten/kota pada tahun $\mathrm{p}$ (permulaan)

$\mathrm{Y}^{\prime} \mathrm{ij}=$ Jumlah produksi komoditas $\mathrm{i}$ pada tingkat kecamatan pada tahun $\mathrm{t}$ (terakhir)

Yij = Jumlah produksi komoditas $\mathrm{i}$ pada tingkat kecamatan pada tahun $\mathrm{p}$ (permulaan)

Potensi Wilayah Keruangan Komoditas Unggulan Subsektor Tanaman Pangan

Analisa potensi wilayah keruangan dilakukan melalui dua langkah yaitu dengan menggabungkan keunggulan komparatif dan kompetitif dilanjutkan dengan analisis dengan pendekatan keruangan. Adapun konsep kedua analisis tersebut adalah sebagai berikut:

a. Gabungan keunggulan komparatif dan kompetitif Analisis gabungan (superimpose) merupakan analisis yang dilakukan dengan menggabungkan (bukan penjumlahan) antara analisis Location Quotient (LQ) dan analisis Shift Share Analysis (SSA) yaitu pada komponen pertumbuhan pangsa wilayah (PPWij). Komoditas yang memiliki unggulan komparatif (nilai LQ > 1) dan kompetitif (nilai PPWij positif) maka masuk dalam komoditas sangat unggul. Sedangkan komoditas yang hanya memiliki unggulan komparatif atau kompetitif maka masuk dalam komoditas unggul.

b. Analisis dengan pendekatan keruangan

Analisis dengan pendekatan keruangan komoditas unggulan tanaman pangan dilakukan melalui proses 
overlay dan spatial join yang dibantu dengan software ArcGis 10.2. Analisis tersebut dilakukan dengan mengoverlaykan antara hasil analisis gabungan dan peta administrasi wilayah Provinsi Bali menurut kabupaten/kota. Analisis ini menghasilkan peta wilayah komoditas unggul dan sangat unggul dari setiap komoditas tanaman pangan.

\section{HASIL DAN PEMBAHASAN}

Komoditas Unggulan Komparatif Subsektor Tanaman Pangan Kabupaten/Kota di Provinsi Bali

Komoditas sub-sektor tanaman pangan yang memiliki keunggulan komparatif ditentukan berdasarkan nilai LQ > 1 . Komoditas yang memiliki keunggulan komparatif menunjukkan komoditas tersebut diproduksi melalui dominasi dukungan sumber daya alam, dimana daerah lain tidak mampu memproduksinya. Komoditas unggulan komparatif tanaman pangan di Provinsi Bali dalam penelitian ini tersaji berdasarkan potensi wilayah menurut kabupaten/kota.

Data tabel.1 menunjukkan komoditas padi memiliki keunggulan komparatif di 6 kabupaten (Tabanan, Gianyar, Buleleng, Badung, Karangasem dan Jembrana) karena mamiliki nilai LQ $>1$. Nilai koefisien LQ padi terbesar terdapat di Kabupaten Tabanan yaitu 4,61. Kabupaten Tabanan, Gianyar dan Buleleng merupakan wilayah dengan potensi produksi padi terbesar di Bali. Komoditas jagung juga memiliki keunggulan komparatif di Kabupaten Buleleng, Karangasem, Klungkung, Bangli dan Tabanan. Nilai koefisien LQ terbesar berada di Kabupaten Buleleng yaitu 7,13 dan Kabupaten Karangasem yaitu 4,87 .

Komoditas kedelai di Bali unggul secara komparatif terdapat di Kabupaten Jembrana, Klungkung, Badung, Gianyar dan Tabanan. Kabupaten Jembrana merupakan wilayah dengan produksi kedelai terbesar di Bali karena nilai koefisien LQ mencapai 7,30. Produksi kedelai mencapai 11,67 diikuti Kabupaten Klungkung dengan nilai LQ 2,12.

Kabupaten Badung dan Gianyar. Kabupaten Karangasem juga memiliki keunggulan komparatif komoditas kacang tanah, karena nilai koefisien LQ nya terbesar yaitu mencapai 7,95. Kabupaten lain yang memiliki komoditas kacang tanah unggulan komparatif yaitu Kabupaten Buleleng, Klungkung, Bangli dan Badung.

Komoditas kacang hijau memiliki keunggulan komparatif terbesar di Kabupaten Karangasem dan Buleleng. Nilai koefisien LQ nya masing-masing mencapai 8,78 dan 6,16. Kabupaten lain dengan yang juga memiliki komoditas kacang hijau unggulan komparatif yaitu Kabupaten Jembrana dan Klungkung.

Komoditas tanaman pangan tersebut memiliki keunggulan komparatif di tingkat kabupaten/kota tertentu dikarenakan share produksi di tingkat kabupaten/kota lebih tinggi dibandingkan tingkat provinsi, sehingga nilai koefisien LQ lebih besar dari 1. Sebaliknya komoditas-komoditas yang tidak memiliki keunggulan komparatif di kabupaten/kota tertentu disebabkan karena share produksi lebih rendah dibandingkan dengan di tingkat provinsi. Hal ini mengacu pada devinisi LQ yang merupakan pembagian antara share produksi kabupaten/kota terhadap share produksi provinsi.

Pertumbuhan Komoditas Subsektor Tanaman Pangan Kabupaten/Kota di Provinsi Bali

Pertumbuhan komoditas tanaman pangan dalam penelitian ini meliputi pertumbuhan regional, pertumbuhan proporsional, pertumbuhan pangsa wilayah dan pertumbuhan bersih. Data yang digunakan dalam menganalisis pertumbuhan komoditas tanaman pangan ini merupakan data produksi series tahun 2011-2015 yang bersumber dari Badan Pusat Stastistik.

\section{a. Pertumbuhan Regional}

Analisis pertumbuhan regional tanaman pangan di tingkat regional Bali menurut kabupaten/kota dan jenis komoditas menunjukkan bahwa komoditas tanaman pangan yang mengalami pertumbuhan regional positif atau mengalami peningkatan produksi secara regional, yaitu Kabupaten Jembrana, Kabupaten Gianyar dan Kota Denpasar masingmasing sebesar 0,292; 0,024 dan 0,140. Pertumbuhan regional dari kabupaten lain mengalami penurunan. Penurunan yang paling tajam yaitu Kabupaten Bangli dengan nilai penurunan regional sebesar -0,484. Berikutnya disusul Kabupaten Karangasem dan Kabupaten Klungkung dengan nilai penurunan masing-masing sebesar 0,307 dan 0,209. Adapun penyajian hasil analisis pertumbuhan regional dapat dilihat pada tabel 3 .

Dengan potensi pertanian tanaman pangan di Kabupaten Jembrana, Tabanan dan Badung yang ada, secara regional mengalami peningkatan atau kemajuan. Secara keseluruhan, hal ini disebabkan oleh peningkatan luas panen dari tahun 2013-2015.

Fenomena Kabupaten Tabanan yang mengalami penurunan pertumbuhan regional sebesar 0,093 cukup menarik untuk dibahas, lantaran daerah tersebut terkenal sebagai penghasil padi di Bali. Penurunan tersebut disebabkan karena penurunan jumlah produksi komoditas padi, jagung, kedelai, ubi kayu dan ubi jalar dari 2011 dibandingkan dengan 2015. Secara absolut tiga penurunan jumlah produksi terbesar terjadi pada komoditas padi, yaitu dari 210.762 ton tahun 2011 menjadi 194.122 ton tahun 2015 atau menurun sebesar 16.640 ton. Contoh penurunan jumlah produksi lainnya terjadi pada komoditas jagung yang menurun 2.039 ton, yaitu dari 7.074 ton tahun 2011 menjadi 5.035 ton tahun 2015 dan komoditas ubi jalar menurun 1.086 ton, yaitu dari 1.215 ton tahun 2011 menjadi 129 ton tahun 2015. 
Tabel 1. Rata-Rata Nilai Koefisien LQ Komoditas Tanaman Pangan Kabupaten/Kota di Provinsi Bali Berdasarkan Nilai Produksi Tahun $2011-2015$

\begin{tabular}{|c|c|c|c|c|c|c|c|}
\hline \multirow[b]{2}{*}{ Kabupaten/Kota } & \multicolumn{7}{|c|}{ Rata-Rata Nilai Koefisien LQ Komoditas Subsektor Tanaman Pangan } \\
\hline & Padi & Jagung & Kedelai & Ubi Kayu & Ubi Jalar & $\begin{array}{l}\text { Kacang } \\
\text { Tanah }\end{array}$ & $\begin{array}{c}\text { Kacang } \\
\text { Hijau }\end{array}$ \\
\hline$(1)$ & $(2)$ & (3) & (4) & $(5)$ & (6) & $(7)$ & $(8)$ \\
\hline 1. Jembrana & 1,23 & 0,10 & 6,30 & 0,03 & 0,004 & 0,30 & 1,88 \\
\hline 2. Tabanan & 4,61 & 1,31 & 2,15 & 0,16 & 0,20 & 0,03 & 0,03 \\
\hline 3. Badung & 2,46 & 0,07 & 2,95 & 0,75 & 3,04 & 1,08 & 0,11 \\
\hline 4. Gianyar & 3,91 & 0,57 & 1,94 & 0,53 & 1,46 & 0,69 & 0,71 \\
\hline 5. Klungkung & 0,70 & 2,43 & 3,85 & 2,12 & 0,66 & 2,81 & 0,81 \\
\hline 6. Bangli & 0,62 & 1,94 & 0,09 & 1,66 & 7,24 & 2,41 & - \\
\hline 7. Karangasem & 1,54 & 4,87 & 0,21 & 11,67 & 5,78 & 7,95 & 8,78 \\
\hline 8. Buleleng & 2,79 & 7,13 & 0,19 & 1,52 & 0,07 & 3,17 & 6,16 \\
\hline 9. Denpasar & 0,29 & 0,01 & 0,38 & - & - & 0,005 & 0,01 \\
\hline
\end{tabular}

Sumber: BPS Provinsi Bali, berbagai tahun (data diolah).

Tabel 2. Komoditas Unggulan Komparatif Tanaman Pangan Kabupaten/Kota di Provinsi Bali Berdasarkan Nilai Produksi Tahun $2011-2015$

\begin{tabular}{ll}
\hline \multicolumn{1}{c}{ Kabupaten/Kota } & \multicolumn{1}{c}{ Komoditas Unggulan Komparatif Subsektor Tanaman Pangan } \\
\hline 1. Jembrana & \multicolumn{1}{c}{$(2)$} \\
2. Tabanan & Kedelai, Kacang Hijau, Padi \\
3. Badung & Padi, Kedelai, Jagung \\
4. Gianyar & Ubi Jalar, Kedelai, Padi, Kacang Tanah \\
5. Klungkung & Padi, Kedelai, Ubi Jalar \\
6. Bangli & Kedelai, Kacang Tanah, Jagung, Ubi Kayu \\
7. Karangasem & Ubi Jalar, Kacang Tanah, Jagung, Ubi Kayu \\
8. Buleleng & Ubi Kayu, Kacang Hijau, Kacang Tanah, Ubi Jalar, Jagung, Padi \\
9. Denpasar & Jagung, Kacang Hijau, Kacang Tanah, Padi, Ubi Kayu \\
\hline
\end{tabular}

Sumber: BPS Provinsi Bali, berbagai tahun (data diolah)

Komoditas tanaman pangan yang mengalami pertumbuhan cepat secara proporsional disebabkan oleh jumlah perbandingan komoditas tahun 2015 dan 2011 lebih besar dari pada perbandingan jumlah produksi tanaman pangan tahun 2015 dan 2011 pada wilayah yang sama. Sebaliknya komoditas tanaman pangan yang mengalami perlambatan secara proporsional disebabkan oleh jumlah pebandingan komoditas tahun 2015 dan 2011 lebih kecil dari pada perbandingan jumlah produksi tanaman pangan tahun 2015 dan 2011 di wilayah yang sama.

a. Pertumbuhan Proporsional

Hasil analisis pertumbuhan proporsional (tabel 4 dan tabel 5) menunjukkan komoditas tanaman pangan yang termasuk cepat dalam pertumbuhan proporsional. Komoditas padi termasuk cepat dalam pertumbuhan proporsional di semua kabupaten/kota kecuali Badung. Berbeda dengan komoditas jagung yang mengalami pertumbuhan cepat secara proporsional hanya di Kabupaten Badung. Sementara di kabupaten lain jagung justru mengalami pertumbuhan yang lambat termasuk di wilayah penghasil jagung di Bali, seperti Buleleng dan Karangasem.
Tabel 3. Pertumbuhan Regional Subsektor Tanaman Pangan Menurut Kabupaten/Kota di Provinsi Bali Berdasarkan Nilai Produksi Tahun 2011 - 2015

\begin{tabular}{lcl}
\hline Kabupaten/Kota & $\begin{array}{c}\text { Nilai } \\
\text { Pertumbuhan } \\
\text { Regional }\end{array}$ & Keterangan \\
\hline \multicolumn{1}{c}{$(1)$} & $(2)$ & \multicolumn{1}{c}{$(3)$} \\
\hline 1. Jembrana & 0,292 & Meningkat \\
2. Tabanan & $-0,093$ & Menurun \\
3. Badung & $-0,108$ & Menurun \\
4. Gianyar & 0,024 & Meningkat \\
5. Klungkung & $-0,209$ & Menurun \\
6. Bangli & $-0,484$ & Menurun \\
7. Karangasem & $-0,307$ & Menurun \\
8. Buleleng & $-0,050$ & Menurun \\
9. Denpasar & 0,140 & Meningkat \\
\hline Sumber: BPS Provinsi Bali, berbagai tahun (data diolah)
\end{tabular}


Sedangkan komoditas kedelai mengalami pertumbuhan cepat secara proporsional di Kabupaten Bangli, Gianyar, Badung dan Karangasem. Komoditas ubi kayu mengalami pertumbuhan yang cepat secara proporsional di Kabupaten Jembrana, Gianyar dan Badung. Komoditas ubi jalar juga terdapat peningkatan pertumbuhan secara proporsional di Kabupaten Badung, Karangasem dan Klungkung. Komoditas kacang tanah mengalami pertumbuhan cepat secara proporsional di Kabupaten Jembrana, Gianyar dan Badung. Komoditas ubi jalar juga terdapat peningkatan pertumbuhan secara proporsional di Kabupaten Badung, Karangasem dan Klungkung. Komoditas kacang tanah mengalami pertumbuhan cepat secara proporsional di Kabupaten Tabanan, Badung dan Bangli. Komoditas kacang hijau mengalami pertumbuhan cepat secara proporsional hanya di Kabupaten Gianyar. Komoditas kacang hijau di kabupaten lain mengalami penurunan secara proporsional.

Tabel 4. Pertumbuhan Proporsional Komoditas Tanaman Pangan Menurut Kabupaten/Kota Di Provinsi Bali Tahun 20112015

\begin{tabular}{|c|c|c|c|c|c|c|c|}
\hline \multirow[b]{2}{*}{ Kabupaten/Kota } & \multicolumn{7}{|c|}{ Jenis Komoditas } \\
\hline & Padi & Jagung & Kedelai & $\begin{array}{c}\text { Ubi } \\
\text { Kayu }\end{array}$ & Ubi Jalar & $\begin{array}{c}\text { Kacang } \\
\text { Tanah }\end{array}$ & $\begin{array}{c}\text { Kacang } \\
\text { Hijau }\end{array}$ \\
\hline$(1)$ & $(2)$ & (3) & (4) & (5) & (6) & $(7)$ & (8) \\
\hline 1. Jembrana & 0,04 & $-0,17$ & $-0,56$ & 2,11 & $-1,29$ & $-0,32$ & $-0,79$ \\
\hline 2. Tabanan & 0,01 & $-0,20$ & $-0,25$ & $-0,31$ & $-0,80$ & 1,54 & - \\
\hline 3. Badung & $-0,04$ & 1,04 & 0,36 & 0,03 & 0,77 & 1,35 & - \\
\hline 4. Gianyar & 0,04 & $-0,78$ & 1,20 & 0,08 & $-0,91$ & $-0,48$ & 5,35 \\
\hline 5. Klungkung & 0,43 & $-0,09$ & $-0,13$ & $-0,52$ & 0,004 & $-0,39$ & $-0,14$ \\
\hline 6. Bangli & 0,40 & $-0,28$ & 1,68 & $-0,21$ & $-0,18$ & 0,06 & - \\
\hline 7. Karangasem & 0,22 & $-0,06$ & 0,31 & $-0,16$ & 0,05 & $-0,06$ & $-0,05$ \\
\hline 8. Buleleng & 0,05 & $-0,19$ & $-0,78$ & $-0,12$ & $-0,75$ & $-0,29$ & $-0,52$ \\
\hline 9. Denpasar & 0,02 & - & $-0,55$ & - & - & - & - \\
\hline
\end{tabular}

Sumber: Badan Pusat Statistik Provinsi Bali. Statistik Tanaman Padi dan Palawija Provinsi Bali (Data diolah Berbagai Tahun).

Tabel 5. Komoditas Tanaman Pangan Yang Mengalami Pertumbuhan Cepat Secara Proporsional Tingkat Kabupaten/Kota di Provinsi Bali Berdasarkan Nilai Produksi Tahun 2011 - 2015

\begin{tabular}{cll}
\hline No & \multicolumn{1}{c}{ Kabupaten/Kota } & \multicolumn{1}{c}{ Jenis Komoditas Tanaman Pangan } \\
\hline$(1)$ & \multicolumn{1}{c}{$(2)$} & \multicolumn{1}{c}{$(3)$} \\
\hline 1 & Jembrana & Ubi Kayu, Padi \\
2 & Tabanan & Kacang Tanah, Padi \\
3 & Badung & Kacang Tanah, Jagung, Ubi Jalar, Kedelai, Ubi Kayu \\
4 & Gianyar & Kacang Hijau, Kedelai, Ubi Kayu, Padi \\
5 & Klungkung & Padi, Ubi Jalar \\
6 & Bangli & Kedelai, Padi, Kacang Tanah \\
7 & Karangasem & Kedelai, Padi, Ubi Jalar \\
8 & Buleleng & Padi \\
9 & Denpasar & Padi \\
\hline Sumber: & Badan Pusat Statistik Provinsi & Bali. Statistik Tanaman Padi dan Palawija Provinsi Bali (Data diolah \\
& Berbagai Tahun). &
\end{tabular}

c. Pertumbuhan Pangasa Wilayah

Berdasarkan hasil analisis pangsa wilayah tahun 20112015 menghasilkan komoditas tanaman pangan yang memiliki daya saing tinggi unggul secara kompetitif yang dibandingkan dengan komoditas yang sama di wilayah yang lebih luas, seperti yang tersajikan pada tabel 6 . Tabel tersebut merupakan hasil analisis panga wilayah yang berupa angka-angka yang sudah diterjemahkan hingga dapat menjelaskan komoditas apa saja yang mempunyai daya saing yang tinggi atau unggul secara kompetitif. Adapun hasil analisis yang disajikan menurut komoditas dan wilayah (kabupaten/kota) terlihat pada tabel 6 dan beberapa peta wilayah keunggulan kompetitif menurut kabupaten/kota.

Komoditas kacang tanah memiliki keunggulan kompetitif di semua kabupaten kecuali Denpasar. Komoditas kedelai yang memiliki keunggulan kompetitif di 6 kabupaten, yaitu Kabupaten Tabanan, Gianyar, Bangli, 
Karangasem, Buleleng dan Kota Denpasar. Komoditas ubi kayu memiliki keunggulan kompetitif di 5 kabupaten, yaitu Kabupaten Badung, Gianyar, Bangli, Karangasem dan Buleleng. Komoditas ubi jalar memiliki keunggulan kompetitif di 4 kabupaten, yaitu Kabupaten Tabanan, Gianyar, Bangli dan Karangaem. Komoditas padi juga memiliki keunggulan kompetitif di 4 kabupaten diantaranya Kabupaten Jembrana, Klungkung, Karangasem dan Kota Denpasar. Sedangkan komoditas jagung hanya memiliki keunggulan kompetitif pada Kabupaten Bangli dan Beleleng. Komoditas kacang hijau memiliki keunggulan kompetitif hanya di Kabupaten Buleleng. Sementara itu untuk hasil analisis pangsa wilayah yang menyajikan komoditas tanaman pangan yang memiliki keunggulan kompetitif yang dirinci menurut kecamatan se-Bali.

Tabel 6. Perutumbuhan Pangsa Wilayah Komoditas Tanaman Pangan Menurut Kabupaten/Kota di Provinsi Bali Tahun 2011-2015

\begin{tabular}{|c|c|c|c|c|c|c|c|}
\hline \multirow[b]{2}{*}{ Kabupaten/Kota } & \multicolumn{7}{|c|}{ Jenis Komoditas } \\
\hline & Padi & Jagung & Kedelai & Ubi Kayu & $\begin{array}{c}\text { Ubi } \\
\text { Jalar }\end{array}$ & $\begin{array}{c}\text { Kacang } \\
\text { Tanah }\end{array}$ & $\begin{array}{c}\text { Kacang } \\
\text { Hijau }\end{array}$ \\
\hline (1) & (2) & (3) & (4) & (5) & $(6)$ & (7) & (8) \\
\hline 1.Jembrana & 1,169 & $-0,960$ & $-0,367$ & - & - & 5,525 & $-0,380$ \\
\hline 2.Tabanan & $-0,026$ & $-2,845$ & 3,517 & $-0,681$ & 0,543 & 0,802 & - \\
\hline 3 .Badung & $-0,327$ & $-2,796$ & $-0,568$ & 0,200 & $-1,037$ & 11,380 & - \\
\hline 4.Gianyar & 0,196 & $-0,384$ & 15,228 & 49,332 & 0,185 & 2,217 & $-8,225$ \\
\hline 5 .Klungkung & 0,026 & $-1,233$ & $-1,109$ & $-0,259$ & - & $-0,015$ & - \\
\hline 6.Bangli & $-0,557$ & 0,715 & 14,953 & 0,120 & 0,063 & 5,812 & - \\
\hline 7 .Karangasem & 0,265 & $-0,832$ & 0,374 & 0,177 & 0,246 & 5,586 & - \\
\hline 8 .Buleleng & $-0,371$ & 8,534 & 0,030 & 1,995 & $-0,017$ & 1,541 & 44,218 \\
\hline 9.Denpasar & 0,274 & - & 0,875 & $-0,586$ & $-187,000$ & - & - \\
\hline
\end{tabular}

Sumber: Badan Pusat Statistik Provinsi Bali. Statistik Tanaman Padi dan Palawija Provinsi Bali (Data diolah Berbagai Tahun).

Tabel 7. Komoditas Tanaman Pangan Yang Memiliki Keunggulan Kompetitif Tingkat Kabupaten/Kota di Provinsi Bali Berdasarkan Nilai Produksi Tahun 2011 - 2015

\begin{tabular}{cll}
\hline No & \multicolumn{1}{c}{ Kabupaten/Kota } & \multicolumn{1}{c}{ Komoditas Dengan keunggulan kompetitif } \\
\hline$(1)$ & \multicolumn{1}{c}{$(2)$} & \multicolumn{1}{c}{$(3)$} \\
\hline 1 & Jembrana & Kacang Tanah, Padi \\
2 & Tabanan & Kedelai, Kacang Tanah, Ubi Jalar \\
3 & Badung & Kacang Tanah, Ubi Kayu \\
4 & Gianyar & Ubi Kayu, Kedelai, Kacang Tanah, Padi, Ubi Jalar \\
5 & Klungkung & Padi \\
6 & Bangli & Kedelai, Kacang Tanah, Jagung, Ubi Kayu, Ubi Jalar \\
7 & Karangasem & Kacang Tanah, Kedelai, Padi, Ubi Jalar, Ubi Kayu \\
8 & Buleleng & Kacang Hijau, Jagung, Ubi Kayu, Kacang Tanah, Kedelai \\
9 & Denpasar & Kedelai, Padi \\
\hline
\end{tabular}

Sumber: Badan Pusat Statistik Provinsi Bali. Statistik Tanaman Padi dan Palawija Provinsi Bali (Data diolah Berbagai Tahun).

Secara wilayah, terdapat 4 kabupaten yang memiliki komoditas paling banyak yang unggul secara kompetitif. Diantaranya Kabupaten Gianyar, Bangli, Karangasem dan Buleleng. Sebaliknya terdapat juga kabupaten yang hanya memiliki 1 komoditas unggulan kompetitif, yaitu Kabupaten Klungkung. Kabupaten Klungkung merupakan kabupaten yang terkecil di Bali. Secara potensi, di Kabupaten Klungkung tidak terdapat banyak padi, namun secara kompetisi padi di Klungkung memiliki daya saing yang baik diantara komoditas tanaman pangan yang lain. Secara teori jika terdapat banyak komoditas yang mempunyai keunggulan kompetitif di suatu wilayah maka akan berdampak semakin tumbuh pangsa wilayah yang bersaing pertumbuhan secara ekonomi. Pertumbuhan secara ekonomi tersebut tentunya tidak lepas dari peran pemerintah dalam upaya menumbuhkembangkan sektor pertanian terutama tanaman pangan.

Fenomena keunggulan kompetitif di Kota Denpasar pada komoditas padi dan kedelai cukup menarik untuk dibahas. Komoditas padi tersebut unggul secara kompetitif karena share dari selisih produksi kecamatan tahun 2011-2015 lebih besar dari share selisih produksi kebupaten/kota tahun 2011-2015. Hal yang sama juga terjadi pada komoditas kedelai.

d. Pertumbuhan Bersih

Analisis pertumbuhan bersih menurut kabupaten/kota (tabel 8) menampilkan komoditas tanaman pangan yang mengalami kemajuan maupun perlambatan dalam 
pertumbuhan bersih. Komoditas padi mengalami kemajuan dalam pertumbuhan bersih di semua kabupaten kecuali Kabupaten Badung. Komoditas jagung mengalami kemajuan pertumbuhan bersih pada wilayah Kabupaten Buleleng dan Badung. Perolehan komoditas kedelai juga cukup mengejutkan dengan kemajuan pertumbuhan bersih di 6 kabupaten, yaitu Tabanan, Badung, Gianyar, Bangli, Karangasem, dan Kota Denpasar. Komoditas ubi kayu juga mengalami kemajuan pertumbuhan bersih di 4 kabupaten, diantaranya Kabupaten Jembrana, Badung, Gianyar, dan Buleleng.

Tabel 8.Pertumbuhan Bersih Komoditas Tanaman Pangan Menurut Kabupaten/Kota di Provinsi Bali Tahun 2011-2015

\begin{tabular}{lcccccrr}
\hline \multirow{2}{*}{ Kabupaten/Kota } & \multicolumn{7}{c}{ Jenis Komoditas Tanaman Pangan } \\
\cline { 2 - 7 } & Padi & Jagung & Kedelai & Ubi Kayu & Ubi Jalar & $\begin{array}{c}\text { Kacang } \\
\text { Tanah }\end{array}$ & $\begin{array}{c}\text { Kacang } \\
\text { Hijau }\end{array}$ \\
\hline 1) & \multicolumn{1}{c}{$(2)$} & \multicolumn{1}{c}{$(3)$} & \multicolumn{1}{c}{$(4)$} & \multicolumn{1}{c}{$(5)$} & $(6)$ & \multicolumn{1}{c}{$(7)$} & $(8)$ \\
\hline 1 .Jembrana & 1,345 & $-1,829$ & $-3,142$ & 10,532 & $-6,461$ & 3,949 & $-4,311$ \\
2 .Tabanan & 0,116 & $-4,796$ & 1,021 & $-3,766$ & $-7,464$ & 16,177 & - \\
3 .Badung & $-0,563$ & 3,462 & 1,586 & 0,390 & 3,556 & 19,483 & - \\
4 .Gianyar & 0,489 & $-5,871$ & 23,602 & 49,895 & $-6,169$ & $-1,153$ & 29,232 \\
5 .Klungkung & 1,733 & $-1,609$ & $-1,615$ & $-2,351$ & 0,017 & $-1,570$ & $-0,573$ \\
6 .Bangli & 1,062 & $-0,418$ & 21,673 & $-0,713$ & $-0,673$ & 6,040 & $-0,573$ \\
7 .Karangasem & 2,046 & $-1,314$ & 2,834 & $-1,121$ & 0,621 & 5,095 & $-0,395$ \\
8 .Buleleng & 0,105 & 6,841 & $-7,013$ & 0,912 & $-6,800$ & $-1,042$ & 39,502 \\
9 .Denpasar & 0,355 & - & 0,875 & $-0,586$ & $-187,000$ & - & - \\
\hline
\end{tabular}

Sumber: Badan Pusat Statistik Provinsi Bali. Statistik Tanaman Padi dan Palawija Provinsi Bali (Data diolah Berbagai Tahun).

Tabel 9. Komoditas Tanaman Pangan Yang Mengalami Kemajuan dan Perlambatan Tingkat Kabupaten/Kota di Provinsi Bali Berdasarkan Nilai Produksi Tahun 2011 - 2015

\begin{tabular}{|c|c|c|c|}
\hline \multirow{2}{*}{ No } & \multirow{2}{*}{$\begin{array}{l}\text { Kabupaten/Kot } \\
\text { a }\end{array}$} & \multicolumn{2}{|c|}{ Komoditas Tanaman Pangan } \\
\hline & & Mengalami Kemajuan & Mengalami Perlambatan \\
\hline (1) & $(2)$ & $(3)$ & $(4)$ \\
\hline 1 & Jembrana & Ubi Kayu, Kacang Tanah, Padi & Jagung, Kedelai, Ubi Jalar, Kacang Hijau \\
\hline 2 & Tabanan & Kacang Tanah, Kedelai, Padi & Jagung, Ubi Kayu, Ubi Jalar, Kacang Hijau \\
\hline 3 & Badung & $\begin{array}{l}\text { Kacang Tanah, Ubi Jalar, Jagung, } \\
\text { Kedelai, Ubi Kayu }\end{array}$ & Padi, Kacang Hijau \\
\hline 4 & Gianyar & Ubi Kayu, Kacang Hijau, Kedelai, Padi & Jagung, Ubi Jalar, Kacang Tanah \\
\hline 5 & Klungkung & Padi, Ubi jalar & $\begin{array}{l}\text { Jagung, Kedelai, Ubi Kayu, Kacang Tanah, } \\
\text { Kacang Hijau }\end{array}$ \\
\hline 6 & Bangli & Kedelai, Kacang Tanah, Padi & Jagung, Ubi Kayu, Ubi Jalar, Kacang Hijau \\
\hline 7 & Karangasem & Kacang Tanah, Kedelai, Padi & Jagung, Ubi Kayu, Ubi Jalar, Kacang Hijau \\
\hline 8 & Buleleng & Kacang Tanah, Jagung, Ubi Kayu, Padi & Kedelai, Ubi Jalar, Kacang Hijau \\
\hline 9 & Denpasar & Kedelai, Padi & $\begin{array}{l}\text { Jagung, Ubi Kayu, Ubi Jalar, Kacang Tanah, } \\
\text { Kacang Hijau }\end{array}$ \\
\hline
\end{tabular}

Sumber: Badan Pusat Statistik Provinsi Bali. Statistik Tanaman Padi dan Palawija Provinsi Bali (Data diolah Berbagai Tahun).

Komoditas ubi jalar juga mengalami kemajuan pertumbuhan bersih hanya di 3 kabupaten, yaitu Kabupaten Badung, Klungkung dan Karangasem. Komoditas kacang tanah mengalami kemajuan pertumbuhan bersih di Kabupaten Jembrana, Tabanan, Badung, Bangli dan Karangasem. Komoditas kacang hijau mengalami kemajuan pertumbuhan bersih di Kabupaten Gianyar dan Buleleng.

Hal yang menarik dalam hasil analisis pertumbuhan bersih diantaranya, komoditas padi yang mengalami kemajuan pertumbuhan bersih di semua kabupaten kecuali Kabupaten Badung. Dapat dikatakan bahwa wilayah dengan potensi padi yang melimpah atau unggul secara jumlah seperti halnya Kabupaten Tabanan dan Gianyar dan Buleleng ternyata cukup mampu mempertahankan kemajuan terhadap pertumbuhan bersih. Capaian yang luar biasa ini mengungguli komoditas lain. Banyaknya nilai positif pada pertumbuhan bersih menyebabkan komoditas padi banyak mengalami kemajuan di tingkat kabupaten/kota. Pertumbuhan bersih yang terjadi pada komoditas padi di Tabanan tersebut disebabkan karena nilai pertumbuhan pangsa wilayah (PPWij) ositif yang terdapat pada Kecamatan Kerambitan, Tabanan, Kediri dan Marga cenderung lebih dominan atau lebih besar, sehingga 
menutup nilai pertumbuhan pangsa wilayah (PPWij) yang negatif yang terjadi pada kecamatan lain. Faktor lain seperti nilai pertumbuhan proporsional pada komodita padi di Tabanan juga menunjukkan nilai positif, yaitu sebesar 0,01 .

\section{Potensi Wilayah Keruangan Komoditas Unggulan Subsektor Tanaman Pangan Kabupaten/Kota di Provinsi Bali}

\section{a. Gabungan Keunggulan Komparatif dan Kompetitif}

Analisis superimpose menunjukkan semua komoditas tanaman pangan (padi, jagung, kedelai, ubi kayu, ubi jalar, kacang tanah, kacang hijau) termasuk dalam komoditas unggul dan komoditas sangat unggul yang tersebar di 9 kabupaten/kota di Provinsi Bali. Komoditas kacang tanah menjadi komoditas sangat unggul yang terbanyak di tingkat kabupaten/kota di Provinsi Bali. Diantaranya Kabupaten Badung, Bangli, Karangasem dan Buleleng yang menjadi wilayah komoditas kacang tanah sangat unggul. Sedangkan komoditas kedelai, menjadi komoditas unggul terbanyak pada tingkat kabupaten/kota di Provinsi Bali, yaitu sebanyak 7 kabupaten.

Kabupaten Klungkung merupakan wilayah yang paling banyak terdapat komoditas unggul sebanyak 5 komoditas, yaitu padi, jagung, kedelai, ubi kayu dan kacang tanah. Selanjutnya kabupaten lain terdapat komoditas unggul sebanyak antara 1-4 komoditas unggul. Kelompok komoditas sangat unggul paling banyak terdapat di Kabupaten Bangli, Buleleng dan Karangasem sebanyak 4 komoditas. Penjelasan lebih rinci dapat dilihat pada tabel 10 .

Tabel 10. Wilayah Komoditas Tanaman Pangan Sangat Unggul dan Komoditas Tanaman Pangan Unggul di Provinsi Bali Tahun 2011-2015

\begin{tabular}{ccll}
\hline No & $\begin{array}{c}\text { Komoditas } \\
\text { Tanaman } \\
\text { Pangan }\end{array}$ & \multicolumn{1}{c}{ Kabupataten/Kota } \\
\cline { 4 - 4 } & \multicolumn{1}{c}{$(2)$} & \multicolumn{1}{c}{ Wilayah Komoditas Sangat Unggul } & \multicolumn{1}{c}{ Wilayah Komoditas Unggul } \\
\hline$(1)$ & \multicolumn{1}{c}{$(3)$} & \multicolumn{1}{c}{$(4)$} \\
\hline 1 & Padi & Jembrana, Gianyar, Karangasem & Tabanan, Badung, Klungkung, Buleleng, Denpasar \\
2 & Jagung & Bangli, Buleleng & Tabanan, Klungkung, Karangasem \\
3 & Kedelai & Tabanan, Gianyar & Jembrana, Badung, Klungkung, Bangli, \\
4 & Ubi Kayu & Bangli, Karangasem, Buleleng & Karangasem, Buleleng, Denpasar \\
5 & Ubi Jalar & Gianyar, Bangli, Karangasem & Tadung, Gianyar, Klungkung \\
6 & Kacang Tanah & Badung, Bangli, Karangasem, Buleleng & Jembrana, Tabanan, Gianyar, Klungkung \\
7 & Kacang Hijau & Buleleng & Jembrana, Karangasem \\
\hline
\end{tabular}

Sumber: Badan Pusat Statistik Provinsi Bali. Statistik Tanaman Padi dan Palawija Provinsi Bali (Data diolah Berbagai Tahun)

Seperti halnya dengan wilayah yang terkenal dengan kantong potensi padi di Bali, dalam hal ini yaitu Tabanan, Gianyar, Buleleng. Dari ketiga kabupaten tersebut yang memiliki komoditas padi sangat unggul hanya Kabupaten Gianyar. Pekembangan komoditas padi unggul komparatif dan kompetitif hingga tahun 2015 cenderung mengalami penurunan di Kabupaten Tabanan dan Buleleng. Disisi lain Kabupaten Jembrana dan Karangasem secara mengejutkan juga memiliki komoditas padi sangat unggul. Komoditas padi sangat unggul ini artinya unggul sacara komparatif dan unggul secara kompetitif.

Sementara itu, wilayah-wilayah kantong potensi palawija seperti Karangasem dan Bangli juga memiliki komoditas sangat unggul yaitu jagung, ubi kayu, ubi jalar dan kacang tanah. Sedangkan Kabupaten Klungkung justru tidak terdapat komoditas tanaman pangan yang memiliki keunggulan komparatif dan kompetitif. Komoditas ini ternyata tidak hanya unggul dalam komperatif (basis) saja namun juga secara kompetitif. Artinya komoditas ini juga mampu bersaing dengan wilayah lain. Komoditas kacang hijau juga sangat unggul di Kabupaten Buleleng. Peranan Dinas Pertanian masing-masing wilayah sangat diharapkan untuk peningkatan komoditas tanaman pangan. b. Potensi Wilayah Keruangan Komoditas Unggulan Komparatif dan Unggulan Kompetitif

1. Potensi Wilayah Keruangan Komoditas Padi Unggulan Komparatif dan Ungguluan Kompetitif

Berdasarkan hasil analisis pendekatan keruangan yang tertuang dalam peta wilayah komoditas unggul dan sangat unggul (gambar 1), komoditas padi merupakan komoditas sangat unggul pada Kabupaten Jembrana, Gianyar dan Karangasem. Di Kabupaten Jembrana komoditas padi tergolong komoditas sangat unggul karena nilai koefisien LQ lebih sari 1 yaitu 1,23 dan ditambah unggul secara kompetitif. Di Kabupaten Gianyar, komoditas padi juga mempunyai nilai koefisien LQ lebih dari 1 yaitu 3,91 dan ditambah unggul secara kompetitif. Hal serupa juga terjadi di Kabupaten Karangasem dengan nilai koefisien LQ padi 1,54. Selain menjadi komoditas sangat unggul, komoditas padi juga tercatat sebagai komoditas unggul secara komparatif pada Kabupaten Tabanan, Badung dan Buleleng. Masing-masing mendapat nilai koefisien LQ padi sebesar 4,61; 2,46 dan 2,79. Sedangkan komoditas padi di Kabupaten Klungkung dan Denpasar merupakan komoditas unggul secara kompetitif. Kabupaten Bangli tercatat tidak terdapat komoditas padi yang unggul secara komparatif maupun kompetitif. 
Kabupaten Tabanan, Gianyar dan Buleleng mempunyai potensi produksi padi yang dominan di Bali. Hasil penelitian ini mengungkapkan bahwa komoditas padi sebagai komoditas sangat unggul hanya terjadi di satu wilayah penghasil padi yaitu Kabupaten Gianyar. Kabupaten lain dengan komoditas padi sangat unggul terdapat di Kabupaten Jembrana dan Karangasem. Unggul secara komparatif dan kompetitif dikarenakan komoditas padi mengalami peningkatan pertumbuhan dan jumlah produksi tahun 2011 jika dibandingkan dengan tahun 2015. Keunggulan komparatif ini secara produksi mempunyai share yang berlebih sehingga mampu men-suplay di wilayah lain. Selain itu juga unggul secara kompetitif. Komoditas padi di Kabupaten Tabanan dan Buleleng mengalami pertumbuhan yang cenderung menurun jika dibandingkan antara tahun 2011 dan 2015 .

Wilayah-wilayah lain sebagai wilayah pendukung dalam produksi padi Bali seperti Badung secara komparatif juga mempunyai share yang berlebih yang dapat didistribusikan ke wilayah yang kurang. Akan tetapi komoditas padi di wilayah tersebut tidak mempunyai keunggulan kompetitif.

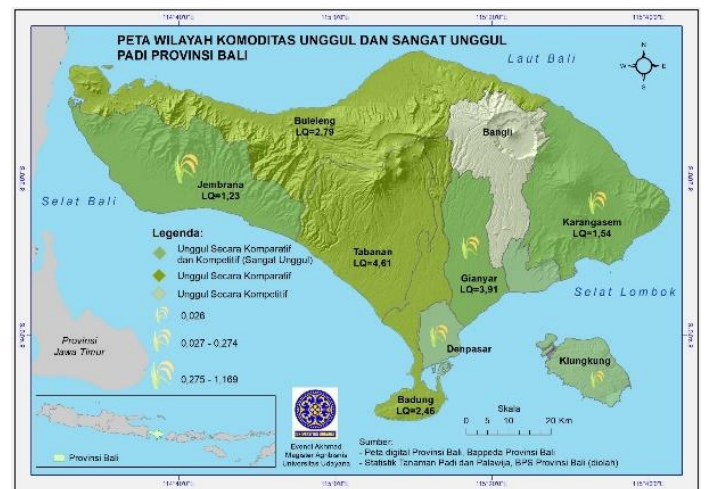

Gambar 1. Peta Wilayah Komoditas Unggul (Secara Komparatif Atau Kompetitif) dan Sangat Unggul (Secara Komparatif dan Kompetitif) Padi Provinsi Bali.

2. Potensi Wilayah Keruangan Komoditas Jagung Unggulan Komparatif dan Ungguluan Kompetitif

Analisis pendekatan keruangan pada gambar 2 menunjukkan potensi komoditas jagung di Provinsi Bali terdapat hampir disemua kabupaten kecuali Kota Denpasar. Penelitian ini menunjukkan dari potensi tersebut terdapat 2 kabupaten yang berpotensi sangat unggul terhadap komoditas jagung, yaitu Kabupaten Buleleng dan Bangli. Besarnya potensi jagung di Buleleng ditunjukkan dengan nilai koefisien LQ yang mencapai 7,13 dan unggul secara kompetitif dengan nilai koefisien pangsa wilayah mencapai 8,534. Sedangkan Kabupaten Bangli potensi komoditas jagung ditinjukan dengan nilai koefisien LQ sebesar 1,94 atau unggul secara komparatif. Keunggulan kompetitif komoditas jagung di Bangli ditunjukkan dengan nilai koefisien pangsa wilayah sebesar 0,715 .

Potensi komoditas jagung di Kabupaten Karangasem, Klungkung dan Tabanan dikategorikan sebagai wilayah komoditas jagung yang unggul secara komparatif. Hal ini artinya komoditas jagung pada kedua wilayah tersebut merupakan komoditas yang unggul dalam jumlah produksi, kendati secara daya saing masih lebih rendah dibanding wilayah lain (Buleleng dan Bangli) yang komoditasnya unggul secara komparatif dan kompetitif. Keunggulan komoditas jagung secara komparatif di Karangasem, Klungkung dan Tabanan masing masing mendapat nilai koefisien LQ sebesar 4,87; 2,43 dan 1,31.

Sedangkan di kabupaten lain yaitu Kabupaten Jembrana, Badung, Gianyar dan Kota Denpasar tidak terdapat komoditas jagung yang unggul secara komparatif maupun unggul secara kompetitif. Hasil analisis dengan pendekatan keruangan secara lengkap tersaji dalam peta wilayah komoditas jagung unggul dan sangat unggul pada gambar 2 .

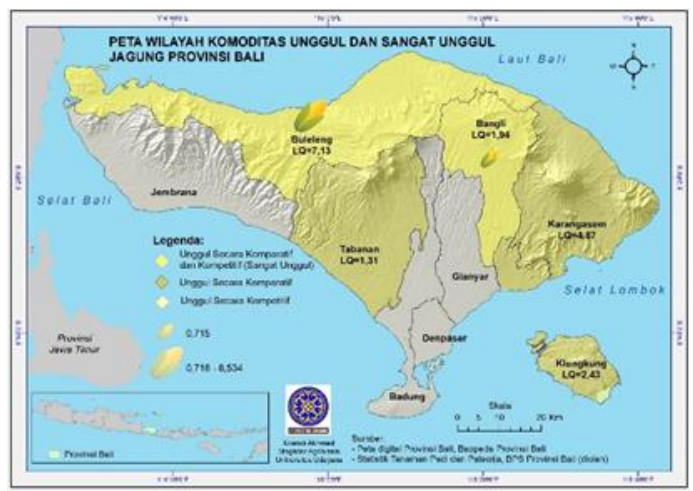

Gambar 2. Peta Wilayah Komoditas Unggul (Secara Komparatif Atau Kompetitif) dan Sangat Unggul (Secara Komparatif dan Kompetitif) Jagung Provinsi Bali.

3. Potensi Wilayah Keruangan Komoditas Kedelai Unggulan Komparatif dan Ungguluan Kompetitif

Menurut hasil analisis peta wilayah komoditas unggul dan sangat unggul pada komoditas kedelai di Provinsi Bali menunjukkan Kabupaten Tabanan dan Kabupaten Gianyar sebagai wilayah dengan komoditas kedelai sangat unggul. Komoditas kedelai di kedua kabupaten tersebut selain unggul secara kompetitif juga unggul secara komparatif (basis).

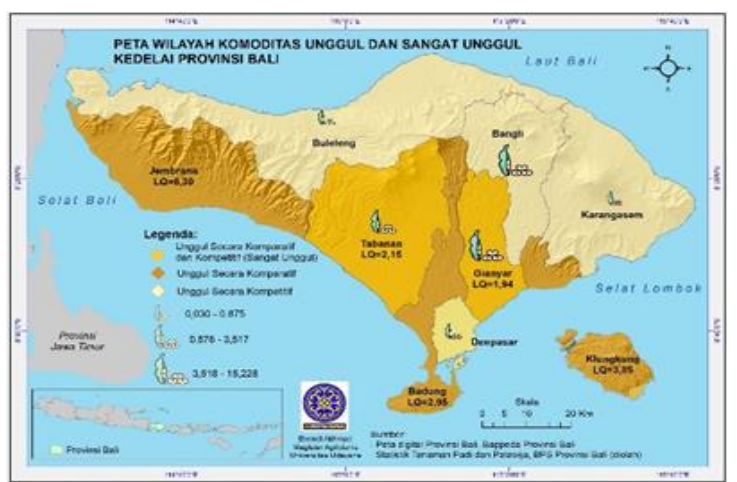

Gambar 3. Peta Wilayah Komoditas Unggul (Secara Komparatif Atau Kompetitif) dan Sangat Unggul (Secara Komparatif dan Kompetitif) Kedelai Provinsi Bali.

Peta wilayah komoditas unggul dan sangat unggul pada komoditas kedelai Provinsi Bali juga menunjukkan wilayah Kabupaten Bangli, Karangasem, Buleleng dan 
Kota Denpasar sebagai wilayah dengan potensi kedelai yang unggul secara kompetitif. Sehingga komoditas kedelai pada kedua wilayah tersebut termasuk dalam komoditas unggul. Keunggulan kompetitif tersebut tercermin dalam pertumbuhan pangsa wilayah dengan nilai koefisien masing-masing 14,953; 0,$374 ; 0,030$. Disamping unggul secara kompetitif, wilayah Bali juga terdapat keunggulan komoditas kedelai secara komparatif, yaitu Kabupaten Jembrana, Kabupaten Klungkung dan Kabupaten Badung. Komoditas kedelai Kabupaten Jembrana unggul secara komparatif dengan nilai koefisien LQ 6,30. Sedangkan komoditas kedelai Kabupaten Klungkung unggul secara komparatif dengan nilai koefisien LQ 3,85 dan di Kabupaten Badung nilai koefisien LQ komoditas kedelai mencapai 2,95.

Dalam 10 tahun terakhir ini, komoditas kedelai mampu menjadi komoditas unggulan secara komparatif maupun kompetitif di Kabupaten Gianyar dan Tabanan. Selain karena produksi yang melimpah, faktor daya saing yang baik pun menjadi alasan mengapa komoditas ini menjadi komoditas sangat unggul. Fenomena lain yang menarik yaitu, kendati rata-rata produksi kedelai Kabupaten Gianyar (13 persen) dan Tabanan (9 persen) yang tergolong masih dibawah Jembrana (33 persen), ternyata produksi kedelai di kedua kabupaten tersebut mampu menjadi komoditas sangat unggul. Bahkan kontribusi komoditas kedelai di Kabupaten Karangasem, Buleleng dan Kota Denpasar yang tergolong kecil mampu bersaing dengan baik, sehingga menjadi unggul secara kompetitif.

4. Potensi Wilayah Keruangan Komoditas Ubi Kayu Unggulan Komparatif dan Ungguluan Kompetitif

Hasil analisis komoditas ubi kayu dengan pendekatan keruangan di Provinsi Bali seperti yang terlihat pada gambar 4 menunjukkan komoditas ubi kayu menjadi komoditas sangat unggul di Kabupaten Karangasem, Bangli dan Kabupaten Buleleng. Terlihat potensi basis (keunggulan komparatif) ubi kayu di Kabupaten Karangasem cukup besar dengan nilai koefisien LQ mencapai 11,67. Nilai koefisien LQ Kabupaten Bangli mencapai 1,66. Sedangkan potensi ubi kayu di Kabupaten Buleleng juga menjadi basis dengan nilai koefisien LQ 1,52. Disamping memiliki kunggulan komparatif (basis), kedua kabupaten tersebut juga memiliki keunggulan kompetitif.

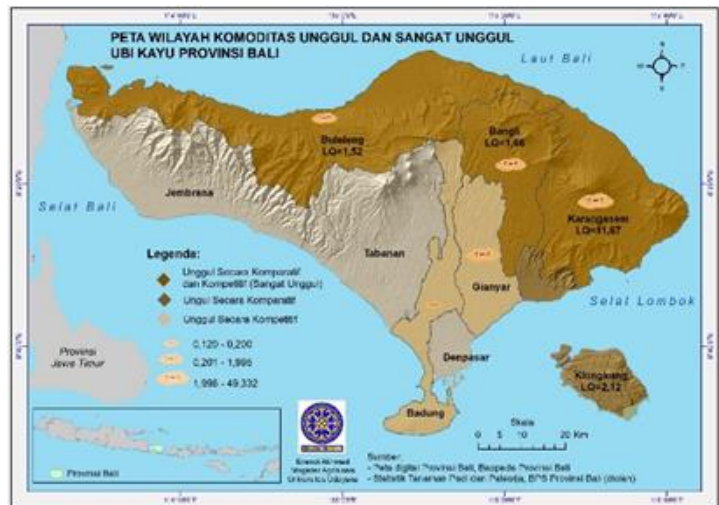

Gambar 4. Peta Wilayah Komoditas Unggul (Secara Komparatif Atau Kompetitif) dan Sangat Unggul (Secara Komparatif dan Kompetitif) Ubi Kayu Provinsi Bali.

Informasi lain yang dapat diambil dari peta wilayah komoditas unggul dan sangat unggul pada komoditas ubi kayu di Provinsi Bali yaitu, potensi komoditas ubi kayu di Kabupaten Klungkung. Kabupaten tersebut merupakan wilayah komoditas unggul dengan komoditas ubi kayu atau wilayah basis yang ditandai dengan nilai koefisien LQ sebesar 2,12. Kondisi komoditas unggul yang berbeda terdapat di Kabupaten Badung dan Gianyar. Potensi ubi kayu di Kabupaten Badung dan Gianyar menjadi komoditas unggul karena mendapat unggul secara kompetitif di wilayah tersebut. Nilai koefiesin pertumbuhan pangsa wilayah masing-masing 49,332 dan 0,2. Sementara itu, Kabupaten Jembrana, Tabanan, dan Kota Denpasar potensi komoditas ubi kayu belum menjadi komoditas unggul dan sangat unggul.

Secara rata-rata produksi ubi kayu tahun 2011-2015 Kabupaten Karangasem paling mendominasi di Bali, angkanya mencapai 86 persen dari total produksi ditingkat provinsi. Karena unggul dari sisi basis inilah Karangasem mampu men-suplay ubi kayu ke wilayah lai di Bali terutama pada wilayah dengan pasar terbesar seperti Denpasar. Sementara Kabupaten Buleleng yang produksinya hanya 11 persen saja juga mampu menjadi komoditas sangat unggul. Sedangkan Kabupaten Klungkung yang juga menjadi wilayah basis ubi kayu mampu menghasilkan 16 persen. Kendati tidak memiliki keunggulan kompetitif, Kabupaten Klungkung juga dapat dipastikan dapat mendistribusikan sebagain hasil ubi kayu ke wilayah lain. Secara keruangan Karangasem, Klungkung, Buleleng dan Bangli mampu memenuhi kebutuhan ubi di wilayah masing-masing.

5. Potensi Wilayah Keruangan Komoditas Ubi Jalar Unggulan Komparatif dan Ungguluan Kompetitif

Berdasarkan hasil analisis dengan pendekatan keruangan (gambar 5) menunjukkan bahwa komoditas ubi jalar di Bali sangat unggul di Kabupaten Bangli, Karangasem dan Gianyar. Kabupaten Bangli merupakan kabupaten paling dominan, dan unggul secara komparatif yang ditandai dengan nilai koefisien LQ 7,24 disusul Kabupaten Karangasem dengan nilai koefisien LQ 5,78. Berikutnya Kabupaten Gianyar dengan nilai koefisien LQ 1,46. Selain unggul secara komparatif, keempat kabupaten tersebut juga unggul secara kompetitif. Ini artinya komoditas ubi jalar mampu bersaing dengan baik di wilayah tersebut.

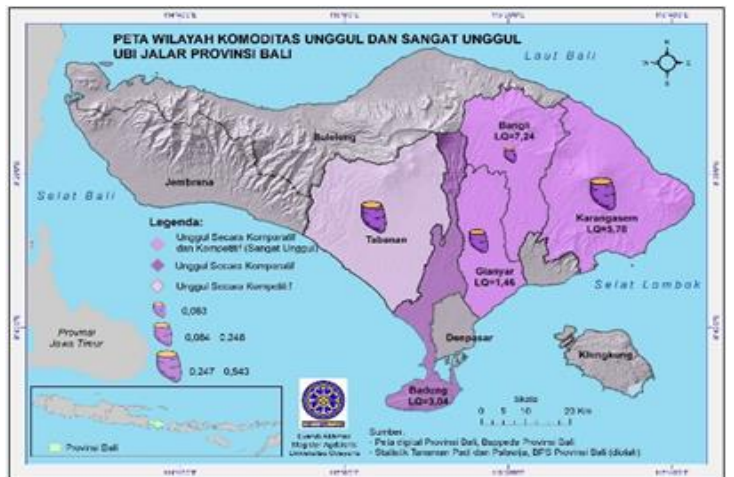

Gambar 5. Peta Wilayah Komoditas Unggul (Secara Komparatif Atau Kompetitif) dan Sangat Unggul (Secara Komparatif dan Kompetitif) Ubi Jalar Provinsi Bali.

Komoditas ubi jalar yang unggul secara kompetitif hanya terjadi di Kabupaten Tabanan. Komoditas ini mampu bersaing dengan baik di Kabupaten Tabanan dengan nilai koefisien pangsa wilayah sebesar 0,543 walaupun secara

Evendi, Komoditas...|86 
jumlah masih terlampau jauh dengan wilayah lain. Senada dengan Kabupaten Tabanan yang hanya unggul secara kompetitif saja, Kabupaten Badung juga hanya unggul secara komparatif saja. Nilai koefisien LQ mencapai 3,04. Namun komoditas ini tidak mampu bersaing dengan baik di Karangasem, sehingga hanya memperoleh keunggula secara komparatif. Sementara itu di wilayah lain seperti Kabupaten Jembrana, Klungkung, Buleleng dan Denpasar tidak terdapat keunggulan komparatif maupun kompetitif.

Potensi produksi ubi jalar di Bali secara rata-rata didominasi di Kabupaten Bangli yang mencapai 39 persen sementara Kabupaten Karangasem mencapai 30 persen dari total produksi Bali. Sementara produksi di kabupaten lain antara 0-16 persen. Tak mengherankan jika hasil produksi dari kedua kabupaten itu termasuk dalam kategori sangat unggul. Selain mampu berdaya saing dengan baik juga mampu men-suplay ke wilayahwilayah lain yang masih kekurangan ubi jalar. Komoditas ubi jalar di Kabupaten Bangli tersebar di semua kecamatan. Sedangkan di Kabupaten Karangasem ubi jalar dominan dihasilkan dihasilkan disemua kecamatan kecuali Kecamatan Manggis. Hasil panen ubi jalar yang melimpah di kedua kabupaten tersebut tidak lepas dari faktor eksternal, yaitu curah hujan yang cukup. Perlu diketahui bahwa tidak semua petani di Bali yang menanam ubi jalar dipanen dan mengambil ubi jalar sebagai hasil akhir, tetapi terdapat banyak petani yang memanen dauh ubi jalar untuk pakan ternak terutama ternak babi.

6. Potensi Wilayah Keruangan Komoditas Kacang Tanah Unggulan Komparatif dan Ungguluan Kompetitif

Melalui analisis dengan pendekatan keruangan dapat diambil informasi bahwa potensi komoditas kacang tanah di Kabupaten Karangasem, Buleleng, Bangli dan Badung menjadi komoditas yang sangat unggul. Penetapan komoditas sangat unggul tersebut didasarkan pada hasil analisis LQ dengan nilai koefisien masing-masing sebesar 7,95; 3,17; 2,41 dan 1,08. Dengan nilai LQ lebih dari 1 menjadikan wilayah tersebut sebagai wilayah basis kacang tanah. Tak hanya sebagai wilayah basis, penetapan komoditas sangat unggul kacang tanah di empat kabupaten tersebut juga didasarkan pada hasil pertumbuhan pangsa wilayah dengan nilai positif yang sekaligus sebagai komoditas yang unggul secara kompetitif. Nilai koefisien pangsa wilayah tersebut masing-masing 5,586 untuk Karangasem, 1,541 untuk Buleleng, 5,812 untuk Bangli, dan 11,380 untuk Badung.

Tak hanya sebagai komoditas sangat unggul, hasil analisis keruangan juga menghasilkan informasi bahwa kacang tanah juga menjadi komoditas unggul yang didasarkan pada keunggulan komparatif. Potensi keunggulan komparatif tersebut terjadi pada Kabupaten Klungkung dengan nilai Koefisien LQ 2,81. Kabupaten Klungkung menjadi satu-satunya wilayah yang hanya terdapat keunggulan secara komparatif. Selain unggul secara komparatif, kacang tanah juga unggul secara kompetitif di wilayah Kabupaten Jembrana, Tabanan dan Gianyar. Gambaran potensi kacang tanah di Provinsi Bali secara keruangan dapati dilihat pada gambar 6 .

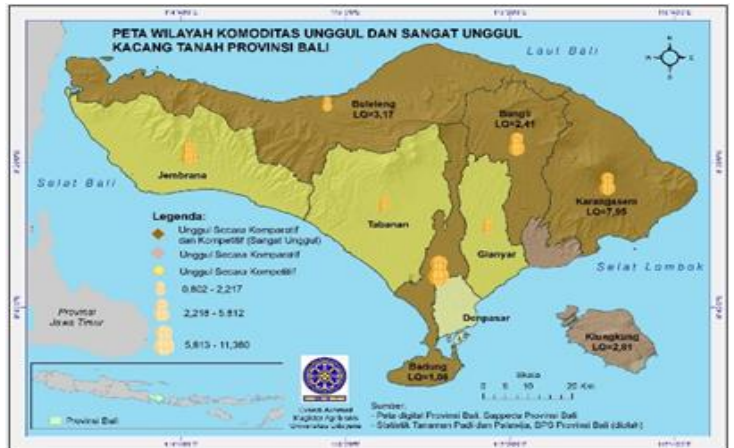

Gambar 6. Peta Wilayah Komoditas Unggul (Secara Komparatif Atau Kompetitif) dan Sangat Unggul (Secara Komparatif dan Kompetitif) Kacang Tanah Provinsi Bali.

Potensi komoditas kacang tanah di Kabupaten Karangasem dihasilkan dari seluruh kecamatan, terutama Kecamatan Kubu yang dominan menghasilkan kacang tanah. Hal sama juga terjadi di Kabupaten Bangli, Kecamatan Kintamani sebagai yang dominan menghasilkan kacang tanah. Kecamatan Nusa Penida dan Banjarangkan merupakan dua kecamatan yang dominan mengahsilkan kacang di Kabupaten Klungkung. Sedangkan potensi dominan di Kabupetan Buleleng berada di Kecamatan Gerokgak dan Kubutambahan. Kabupaten Badung didominasi di Kecamatan Petang. Jika ditengok menurut rata-rata produksi di tiga kabupaten yang berpotensi sangat unggul tersebut mencapai 76 persen dari total produksi di Bali. Sedangakan sisanya antara $0-11$ persen saja. Hal ini senada dengan karakteristik tempat penanaman yang cocok untuk kacang tanah.

7. Potensi Wilayah Keruangan Komoditas Kacang Hijau Unggulan Komparatif dan Ungguluan Kompetitif

Hasil analisis keruangan pada peta wilayah komoditas unggul dan sangat unggul di Provinsi Bali (gambar 7) menempatkan komoditas kacang hijau sebagai komoditas yang sangat unggul hanya di wilayah Kabupaten Buleleng. Dikatakan sangat unggul didasarkan pada hasil analisis LQ dengan perolehan koefisien sebesar 6,16 serta dengan nilai koefisien pertumbuhan pangsa wilayah sebesar 44,218. Atas dasar kedua analisis tersebut komoditas kacang hijau unggul secara komparatif dan kompetitif di Kabupaten Buleleng.

Informasi selanjutnya yang dapat diambil dari analisis keruangan pada peta wilayah komoditas yaitu komoditas kacang hijau juga menjadi komoditas unggul secara komparatif di Kabupaten Jembrana dan Karangasem. Besarnya potensi kacang hijau di Kabupaten Jembrana tercermin dari hasil analisisLQ dengan perolehan nilai koefisien sebesar 1,88. Dengan nilai koefisien tersebut, komoditas kacang hijau menjadi basis di Kabupaten Jembrana. Hal ini yang menjadi dasar sebagai komoditas unggul. Hal yang sama juga terjadi di Kabupaten Karangasem. Dengan nilai koefisien LQ sebesar 8,78 menjadikan komoditas kacang hijau sebagai komoditas unggul di Kabupaten Jembrana. 


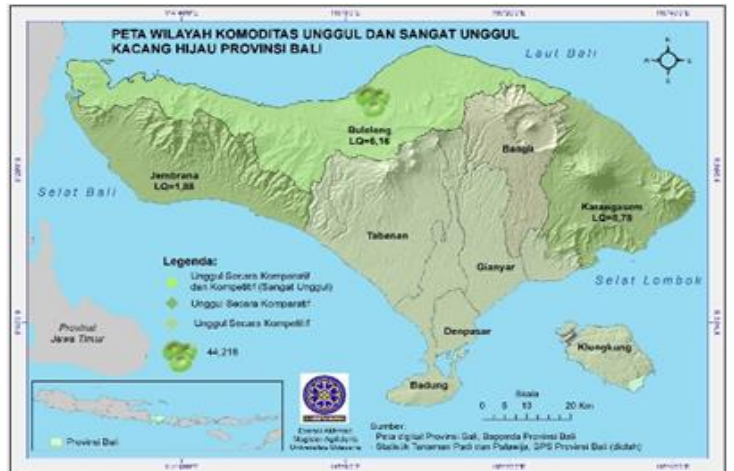

Gambar 7. Peta Wilayah Komoditas Unggul (Secara Komparatif Atau Kompetitif) dan Sangat Unggul (Secara Komparatif dan Kompetitif) Kacang Hijau Provinsi Bali.

Sementara itu kabupaten lain (Tabanan, Badung, Gianyar, Klungkung dan Kota Denpasar) belum dapat dikategorikan sebagai wilayah yang menghasilkan komoditas kacang hijau unggulan, baik secara komparatif maupun kompetitif. Hal ini dikarenakan nilai analisis LQ kurang dari 1 dan nilai pertumbuhan pangsa wilayah negatif. Sedangkan Kabupaten Bangli tidak terdapat produksi kacang hijau.

Kabupaten Buleleng kendati secara jumlah masih kalah banyak dibanding dengan Kabupaten Karangasem namun komoditas ini mampu berdaya saing dengan baik. Potensi kcang hijau di Kabupaten Buleleng terdapat di semua kecamatan kecuali Kecamatan Busungbiu dan Tejakula. Sementara di Kabupaten Jembrana potensi tersebut terdapat di Kecamatan Melaya, Negara dan Mendoyo. Potensi kacang hijau di Kabupaten Karangasem hanya terdapat di Kecamatan Kubu. Secara rata-rata LQ 20112015 Kabupaten Karangasem dan Kabupaten Jembrana dapat dikatakan mampu men-suplay sebagian produksinya untuk kebutuhan di wilayah lain, kendati daya saing komoditas di wilayah tersebut masih rendah.

\section{SIMPULAN DAN SARAN}

\section{Simpulan}

Simpulan dari penelitian ini adalah sebagai berikut: komoditas tanaman pangan unggulan komparatif di Kabupaten Jembrana meliputi kedelai, kacang hijau dan padi. Kabupaten Tabanan meliputi padi, kedelai dan jagung. Kabupaten Badung meliputi kedelai, padi, ubi jalar, kedelai dan kacang tanah. Kabupaten Gianyar meliputi padi, kedelai dan ubi jalar. Kabupaten Klungkung meliputi kacang tanah, kedelai, ubi kayu dan jagung. Kabupaten Bangli meliputi ubi jalar, jagung, kacang tanah dan ubi kayu. Kabupaten Karangasem meliputi ubi kayu, kacang hijau, kacang tanah, ubi jalar, jagung dan padi. Kabupaten Buleleng meliputi jagung, kacang hijau, padi, kacang tanah, kacang hijau dan ubi kayu. Kota Denpasar tidak memiliki komoditas unggulan komparatif pertumbuhan regional komoditas tanaman pangan terjadi di tiga kabupaten/kota, yaitu Kabupaten Jembrana, Gianyar dan Denpasar menunjukkan peningkatan. Semua kabupaten/kota memiliki komoditas tanaman pangan yang mengalami pertumbuhan yang cepat secara proporsional. Semua kabupaten/kota juga memiliki komoditas dengan keunggulan kompetitif dan miliki komoditas yang mengalami kemajuan dalam pertumbuhan bersih; potensi komoditas tanaman pangan dengan pendekatan keruangan kabupaten/kota di Provinsi
Bali menunjukkan bahwa semua wilayah kabupaten/kota memiliki komoditas unggulan tanaman pangan, baik yang tergolong unggul (komparatif atau kompetitif) maupun sangat unggul (komparatif dan kompetitif). Terkecuali Kota Denpasar yang hanya memiliki komoditas tanaman pangan unggul.

\section{Saran}

Saran yang dapat diajukan dari hasil penelitian ini meliputi: guna mempertahankan dan meningkatkan komoditas basis tanaman pangan di Provinsi Bali, diharapkan pemerintah lebih mengarahkan pada pembangunan sektor pertanian terutama tanaman pangan dengan fokus pada: upaya untuk mempertahankan lahan produktif pertanian sebagai media utama produksi komoditas tanaman pangan, meningkatkan produktivitas tanaman pangan dengan meningkatkan intensifikasi pertanian, mengembangkan dan mensosialisasikan komoditas tanaman pangan umbi-umbian (ubi kayu, ubi jalar) sebagai komoditas tanaman pangan substitusi dari komoditas tanaman pangan jenis padi-padian sehingga pertumbuhan daya saing komoditas non padi-padian dapat lebih meningkat; Pemerintah Provinsi Bali bersama Pemerintah Kabupaten/Kota perlu bekerjasama dan saling bersinergi mengembangkan potensi komoditas tanaman pangan yang dimiliki masing-masing wilayah guna menjaga dan meningkatkan komoditas unggulan serta pertumbuhan dan efisiensi komoditas tanaman pangan. Upaya pengembangan potensi tanaman pangan tersebut diharapkan sesuai dengan Peraturan Gubernur No. 99 Tahun 2018 tentang Pemesaran dan Pemanfaatan Produk Pertanian dan industri Lokal Bali dan Peraturan Gubernur No. 6 Tahun 2018 tentang Rencana Aksi Daerah Pangan dan Gizi Provinsi Bali serta tertuang dalam Materi Teknis (Matek) Daerah dan masuk dalam agenda Rapat Paripurna Dewan Daerah (Rapenda) kabupaten/kota; komoditas unggul dan sangat unggul pada penelitian ini hanya memperhitungkan dari sisi basis (keunggulan komparatif) dan keunggulan secara kompetitif. Kedua keunggulan tersebut tidak sematamata sesuai dengan zona agroklimat. Terkait pada penelitian selanjutanya perlu dilakukan hal-hal sebagai berikut: dibutuhkan kajian lebih lanjut yang memperhitungkan dari sisi aspek agroklimat sampai pada keunggulan pada tiap zona, guna mendukung ketahanan pangan diperlukan data series tentang sumber pangan yang lain, data konsumsi sampai pada level rumah tangga, tingkat daya beli atau pengeluaran penduduk, hingga aspek potensi tanaman pangan secara spesialisasi dan secara lokalisasi pada masing-masing wilayah kabupaten/kota.

\section{Ucapan Terima Kasih}

Terima kasih disampaikan kepada kepala Badan Pusat Statistik Provinsi Bali dan kepala Pusdiklat Badan Pusat Statistik yang telah memberikan ijin belajar untuk melanjutkan pendidikan program S2 Magister Agribisnis Universitas Udayana dan berbagai pihak yang telah membantu dalam pelaksanaan penelitian ini.

\section{Daftar Pustaka}

[BPS] Badan Pusat Statistik. 2013. Laporan Sensus Pertanian 2013. Denpasar: Badan Pusat Statistik Provinsi Bali. 
[BPS] Badan Pusat Statistik. 2014. Potensi Pertanian Provinsi Bali Analisis Hasil Pendataan Lengkap Sensus Pertanian 2013. Denpasar: Badan Pusat Statistik Provinsi Bali.

[BPS] Badan Pusat Statistik. 2015. Analisis Rumah Tangga Usaha Tanaman Pangan di Indonesia Hasil Survei Rumah Tangga Usaha Tanaman Padi dan Survei Rumah Tangga Usaha Tanaman Palawija 2014. Jakarta: Badan Pusat Statistik.

[BPS] Badan Pusat Statistik. 2016. Luas Lahan Menurut Penggunaannya di Provinsi Bali 2015. Denpasar: Badan Pusat Statistik Provinsi Bali.

[BPS] Badan Pusat Statistik. 2016. Statistik Tanaman Padi dan Palawija Provinsi Bali 2015. Denpasar: Badan Pusat Statistik Provinsi Bali.

[BPS] Badan Pusat Statistik. 2018. Bali Dalam Angka 2017. Denpasar: Badan Pusat Statistik Provinsi Bali..__. 2018. Produk Domestik Regional Bruto Provinsi Bali Menurut Lapangan Usaha 2013-2017. Denpasar: Badan Pusat Statistik Provinsi Bali.

Budiharsono, Sugeng 2001. Teknik Analisis Pembangunan Wilayah Pesisir dan Lautan. Jakarta: Pradnya Paramita

Djaenudin, D., Y. Sulaeman, dan A. Abdurachman. 2002. Pendekatan Pewilayahan Komoditas Pertanian menurut Pedo-Agroklimat di Kawasan Timur Indonesia. Jurnal Litbang Pertanian 21(1):1-10. Available from URL: http://pustaka.litbang.pertanian.go.id/publikasi/p3 211021.pdf. diakses tanggal 24 Maret 2018

Mulyono, Joko dan Munibah, Khursatul. 2016. Pendekatan Location Quotient dan Shift Share Analisis Dalam Penentuan Komoditas Tanaman Pangan Di Kabupaten Bantul. Bogor: Balai Besar Pengkajian dan Pengembangan Teknologi Pertanian. Jurnal Informatika Pertanian Vol. 25 No.2, Desember 2016: 221-230. Available from URL:

http://ejurnal.litbang.pertanian.go.id/index.php/IP /article/view/8569/7397. diakses tanggal 24 Maret 2018.

Prahasta, Eddy. 2014. Sistem Informasi Geografis: Konsep-Konsep Dasar. Bandung. Informatika

Pranoto, Endro. 2008. Potensi Wilayah Komoditas Pertanian Dalam Mendukung Ketahanan Pangan Berbasis Agribisnis Kabupaten Banyumas. Tesis. Semarang: Universitas Diponegoro. Available from URL: http://eprints.undip.ac.id/17408/1/ENDRO_PRA NOTO.pdf. diakses tanggal 24 Maret 2018.

Setiowati, Septiana Tri. 2010. Analisis Komoditas Unggulan Sektor Pertanian di Kabupaten Bangli Provinsi Bali. Tesis. Denpasar: Program Pascasarjana Universitas Udayana.

Sitorus, Santun R.P. Mulya, Setyardi Partika. Iswati, Asdar. Panuju, Dyah Retno dan Iman, La Ode Samsul. 2014. Teknik Penentuan Komoditas
Unggulan Pertanian Berdasarkan Potensi Wilayah Dalam Rangka Pengembangan Wilayah. Seminar Nasional ASPI 2014. Pekanbaru: UIR Press

Susrusa, Ketut Budi. 2008. Identifikasi dan Zonasi Komoditas Pertanian Unggulan di Kabupaten Klungkung. Denpasar: Universitas Udayana.

Syafruddin, A.N. Kairupan, A. Negara, dan J. Limbongan. 2004. Penataan Sistem Pertanian dan Penetapan Komoditas Unggulan Berdasarkan Zona Agroekologi di Sulawesi Tengah. Jurnal Litbang Pertanian. 23(2):61-67. Available from URL:

http://pustaka.litbang.pertanian.go.id/publikasi/p3 232044.pdf. diakses tanggal 24 Maret 2018. 